Journal of Engineering and Applied Sciences 14 (22): 8321-8328, 2019

ISSN: 1816-949X

(C) Medwell Journals, 2019

\title{
Experimental Study of the Strength Performance of Sawdust Ash Pervious Concrete
}

\author{
${ }^{1}$ O.M. Osuolale, ${ }^{2}$ O.D. Atoyebi and ${ }^{2} \mathrm{O}$.V. Tunde \\ ${ }^{1}$ Department of Civil Engineering, Ladoke Akintola University of Technology, \\ Ogbomoso, Oyo State, Nigeria \\ ${ }^{2}$ Department of Civil Engineering, Landmark University, Omu-Aran, Kwara State, Nigeria \\ atoyebi.olumoyewa@1mu.edu.ng
}

\begin{abstract}
Deterioration of highway pavement resulting from flooding is on the increase because of climate change. Previous researches have succeeded in removing the run-off water using pervious concrete but for low traffic density. This research focused on improving the structural performance of pervious concrete for high-density traffic. The 168 test samples of pervious concrete comprising of 54 beams, 54 cubes and 60 cylindrical specimens were cast to undergo slump test, density and void content test, split tensile strength test, flexural strength test, compressive strength test and permeability test. Sawdust ash was added to replace cement with varying percentages of $5,10,15$ and 20 . The result shows that varying percentages of $5,10,15$ and 20 sawdust ash mix exhibit poor mechanical properties.
\end{abstract}

Key words: Pervious concrete, sawdust ash, Civil Engineering, strength, construction, mechanical properties

\section{INTRODUCTION}

Concrete is a composition material made out of coarse aggregate joined securely in proximity with a fluid bond (cement) which solidifies after some time (Sadiq and Atoyebi, 2015; Zaetang et al., 2016; Atoyebi et al., $2018 \mathrm{a}-\mathrm{c}$ ). Concrete types vary with respect to the binder used and some other added materials like hydraulic cement such as calcium aluminate cement in limecrete, asphalt as a binder in asphaltic concrete and polymer concretes with the polymer as the cementing material (Harvey et al., 1995; Fakhrul et al., 2013; Kotwa, 2015; Dutt et al., 2016; Modupe et al., 2019). Pervious concrete which is also, known as permeable concrete is a composition material comprising of Portland cement, coarse aggregate and water. The major difference to ordinary concrete is the absence of fine aggregate in the primary mixture. The aggregate (coarse), more often than not comprises of a solitary size and is reinforced together at its points of contact by a paste moulded with concrete and water. The outcome is concrete with a high rate of interconnected voids that, when working effectively, allow the fast permeation of water through the concrete (Obla, 2010; Mrakovcic et al., 2014; Mahesh and Lavanya, 2016). Pervious concrete has different properties to conventional/normal concrete, normal concrete has a void proportion in the range of $3-5 \%$ compared to void proportions of $15-40 \%$ in pervious concrete depending upon its application (Sharma et al., 2012; Ghosh et al., 2015), since, voids are generally, assumed to lessen the strength of concrete, the desired result is to discover a balance between aggregate, water and cement with a specific end goal to increase the permeability and strength, two characteristics which tend to counteract one another.

Likewise, of vital importance is suitable traffic loads and volumes, so that, the porous concrete can keep up its structural integrity. Meanwhile at present pervious concrete is not recommended for high speed, high traffic roads (Ajamu et al., 2012; Radlinska et al., 2012; Lee et al., 2013). Maguesvari and Narasimha (2013) unveils some applications of pervious concrete: parking lots, alleys and driveways, sidewalks/walkways, swimming pool decks, tennis court, streets/road shoulders, patios, other light traffic areas etc. Some properties of pervious concrete are it allows water to seep through and permeate its surface, $40 \%$ of evapotranspiration, $10 \%$ runoff, $25 \%$ shallow infiltration, $25 \%$ deep infiltration and it has natural ground cover (Collier, 2016). Typical pervious concrete pavements have a $15-20 \%$ void structures. It is consequently lightweight with a density of $1600-1900 \mathrm{~kg} / \mathrm{m}^{3}$ (Ajamu et al., 2012). Patil and Murnal (2014) consider concrete to be durable when it responds to environmental conditions

Corresponding Author: O.D. Atoyebi, Department of Civil Engineering, Landmark University, Omu-Aran, Kwara State, Nigeria atoyebi.olumoyewa@lmu.edu.ng 
satisfactorily within its designed service life, its properties can be enhanced with the use of additional compounds like fly ash (Patil and Murnal, 2014). This research provides a way of improving the mechanical properties of pervious concrete through the partial replacement of cement with sawdust ash and addition of fine sand in variable proportions, enhancing the performance of pervious concrete and meets the requirement of ASTM C618, C989 and C1240, respectively (ASTM., 2003; 2015; ASTM., 2018ab).

\section{MATERIALS AND METHODS}

The materials used in this research are cement, granite as coarse aggregate, fine aggregate, Sawdust Ash (SDA) and water. Type I Portland cement conforming to ASTM. (2018) was used in all mixes a total of 168 test samples comprising of 54 nos $100 \times 100 \times 400 \mathrm{~mm}$ rectangular beams, 54 nos $150 \times 150 \times 150 \mathrm{~mm}$ cubes and 60 nos $100 \times 140 \mathrm{~mm}$ cylindrical specimens were cast. Sawdust ash was used as a mineral additive to partially replace cement with variable proportions $(5,10,15$ and $20 \%$ ) in enhancing the performance of pervious concrete and meets the requirement of ASTM C618, C989 and C1240, respectively (ASTM., 2003, 2015; ASTM., 2018a). The physical and chemical properties of the SDA were determined through different tests at the Chemistry Laboratory, Landmark University, Omu-Aran, Kwara State, Nigeria using Atomic absorption spectrophotometer (Model Analyst 800). The particle size of the SDA in this research passes through a sieve of opening $300 \mu \mathrm{m}$.

Compressive strength test: Three cubes from each pervious concrete batch mix were tested after 7,14 and 28 days of curing. The compressive strength $\left(\mathrm{f}_{\mathrm{c}}\right)$ is given by Eq. 1 (BSI., 2003a):

$$
\mathrm{f}_{\mathrm{CK}}=\frac{\mathrm{F}}{\mathrm{A}_{\mathrm{C}}}
$$

Where:

$\mathrm{f}_{\mathrm{CK}}=$ Compressive strength $\left(\mathrm{N} / \mathrm{mm}^{2}\right)$

$\mathrm{F}=$ Maximum failure load $(\mathrm{N})$

$\mathrm{A}_{\mathrm{C}}=$ Specimen cross-sectional area (BSI., 2003a)

Flexural strength test: Flexural strength test was carried out using the centre-point loading method. Three beams from each pervious concrete batch mix were tested after 7 , 14 and 28 days of curing. The flexural strength is expressed as the modulus of rupture $\left(\mathrm{f}_{\mathrm{cf}}\right)$ which is given by Eq. 2 (BSI., 2009).

$$
f_{c f}=\frac{3 F a}{2 b d^{2}}
$$

Where:

$\mathrm{f}_{\mathrm{cf}}=$ Flexural strength in $\mathrm{MPa}\left(\mathrm{N} / \mathrm{mm}^{2}\right)$

$\mathrm{F}=$ Maximum load at failure $(\mathrm{N})$

$\mathrm{a}=$ Distance between the supporting rollers $(\mathrm{mm})$

$\mathrm{L}=$ Length of beam $(400 \mathrm{~mm})$

$\mathrm{b}=$ Width of beam $(100 \mathrm{~mm})$

$\mathrm{d}=$ Depth of beam $(100 \mathrm{~mm})$

Permeability/hydraulic conductivity test (infiltration rate method): The permeability of pervious concrete is measured at the end of the 28 days. A total of 6 cylindrical specimens were tested for the six pervious concrete batch mix. The permeability of pervious concrete is calculated using the Infiltration rate (I) as given in Eq. 3 (ASTM., 2009):

$$
\mathrm{I}=\frac{\mathrm{KM}}{\mathrm{D}^{2} \mathrm{xt}}(\mathrm{h})
$$

Where:

$\mathrm{K}=126,870$ (inches)

$\mathrm{M}=$ Mass of water $(\mathrm{Ib})$

$\mathrm{D}=$ Diameter of cylinder (inches)

$\mathrm{t}=$ Time to infiltrate $(\mathrm{sec})$

Splitting tensile strength test: Three cylinders from each pervious concrete batch mix were tested after 7,14 and 28 days of curing. The tensile splitting strength $\left(\mathrm{f}_{\mathrm{ct}}\right)$ is given by Eq. 4 (BSI., 2003b; Atoyebi et al., 2018a):

$$
\mathrm{f}_{\mathrm{ct}}=\frac{2 \mathrm{~F}}{\pi \mathrm{Ld}}
$$

Where:

$\mathrm{f}_{\mathrm{ct}}=$ Tensile splitting strength $\left(\mathrm{N} / \mathrm{mm}^{2}\right)$

$\mathrm{F}=$ Failure maximum load $(\mathrm{N})$

$\mathrm{L}=$ Length of the line of contact of the specimen (mm)

$\mathrm{d}=$ Designated cross-sectional dimension ( $\mathrm{mm}$ )

$\pi=$ Greek letter Pi constant value (3.142)

\section{RESULTS AND DISCUSSION}

Characterization of the mineral additives: The result in Table 1 reveals the elemental oxide in the SDA sample having combined percentages of $(\mathrm{SiO}+\mathrm{AlO}+\mathrm{FeO})$ of $73.0 \%$, this indicates that it is a good pozzolanic material in accordance with the requirements by ASTM (2003). The silica content in the SDA (65.65\%) is low as compared to reports on Sawdust Waste Incineration Fly Ash (SWIFA) which is $67.20 \%$ (Elinwa et al., 2008) and corn cob ash with a value of $66.38 \%$ (Adesanya and Raheem, 2009) (Table 1). 


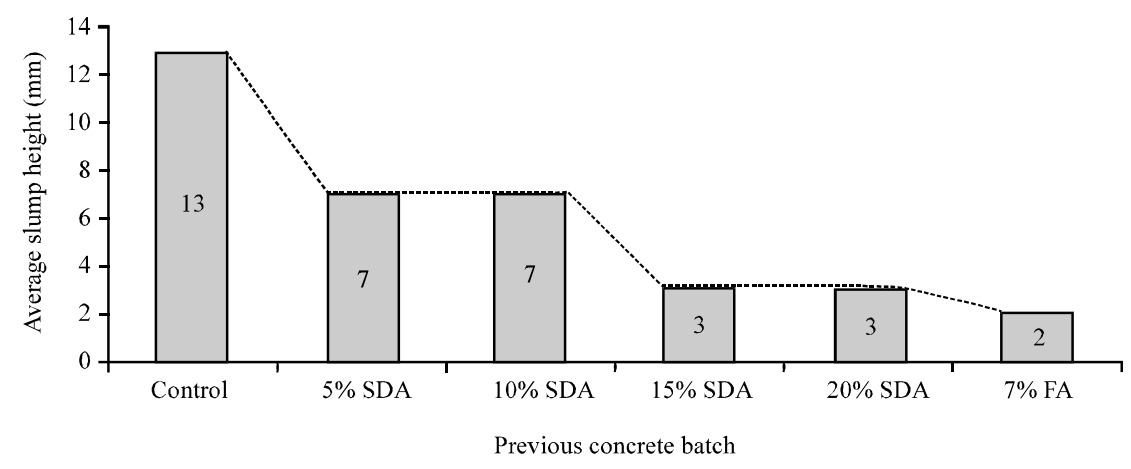

Fig. 1: Slump height vs. pervious concrete batch

Table 1: Chemical composition of SDA

\begin{tabular}{lc}
\hline Chemical constituents & Composition (\%) \\
$\mathrm{SiO}_{2}$ & 65.65 \\
$\mathrm{Al}_{2} \mathrm{O}_{3}$ & 5.22 \\
$\mathrm{Fe}_{2} \mathrm{O}_{3}$ & 2.13 \\
$\mathrm{CaO}$ & 9.62 \\
$\mathrm{MgO}$ & 4.51 \\
$\mathrm{SO}_{3}$ & 1.09 \\
$\mathrm{Na}_{2} \mathrm{O}$ & 0.07 \\
$\mathrm{C}_{2} \mathrm{CO}$ & 7.92 \\
$\mathrm{LOI}$ & 4.30 \\
$\mathrm{Total} \mathrm{SiO}_{2}+\mathrm{Al}_{2} \mathrm{O}_{3}$ & 70.87 \\
Total $\mathrm{SiO}_{2}+\mathrm{Al}_{2} \mathrm{O}_{3}+\mathrm{Fe}_{2} \mathrm{O}_{3}$ & 73.00 \\
\hline
\end{tabular}

Table 2: Phy sical properties of Sawdust Ash (SDA)

\begin{tabular}{lc}
\hline Physical properties & Values \\
\hline Specific Gravity $(\mathrm{G})$ & 2.17 \\
Loose bulk density $\left(\mathrm{kg} / \mathrm{m}^{3}\right)$ & 1040 \\
Loss in ignition $(\%)$ & 4.30 \\
Yield $(\%)$ & 3.00 \\
Moisture content $(\%)$ & 0.30 \\
Particle passing $(\mu \mathrm{m})$ & 300 \\
\hline
\end{tabular}

The loose bulk density, specific gravity and other physical properties of SDA are presented in Table 2. It shows that SDA has a specific gravity lesser than that of cement with a specific gravity of 3.15 .

Slump test: Figure 1 shows that freshly mixed pervious concrete is typically stiff, within a slump range of 0-25 as specified by ASTM (2015) making it a true slump and low workability compared to conventional concrete. Increase in the SDA content causes increase in amount of silica in the concrete and its reaction with lime during cement hydration requires more water, hence, causing a stiff slump (Al-Chaar et al., 2011).

Density and void content of hardened mixed pervious concrete: The density of pervious concrete as shown in Fig. 2 ranges from $1998.51-2380.49 \mathrm{~kg} / \mathrm{m}^{3}$ for the different mix. Densities within the upper range of normal-weight concrete on the order of $2000-2600$ as specified by
BSI. (2003c) were achieved for all except for $20 \%$ SDA which falls a little below it with a value of $1998.51 \mathrm{~kg} / \mathrm{m}^{3}$ (Fig. 2).

The percentage replacement of cement with SDA is inversely proportional to the density giving a $2 \%$ decrease in the pervious concrete density at every $5 \%$ SDA replacement. Moreover, $7 \%$ fine aggregate pervious concrete produced the highest density $2380.49 \mathrm{~kg} / \mathrm{m}^{3}$.

The influence of the SDA on the pervious concrete void content is shown in Fig. 3. As the SDA percentage replacement increases, there is an increase in the pervious concrete void content but a great decrease was recorded at the addition of $7 \%$ fine aggregate to the pervious concrete mix. According to, sika guide to pervious concrete, pervious concrete air void content varies between 15 and $30 \%$. Maximum void content of $16.14 \%$ was achieved and a minimum of $12.08 \%$ for the SDA pervious concrete.

Compressive strength: The maximum compressive strength $24.329 \mathrm{~N} / \mathrm{mm}^{2}$ of at 28 days was obtained from $7 \% \mathrm{FA}$ batch, it is observed that increase in the SDA content is inversely proportional to the pervious concrete compressive strength. Table 3, 20\% SDA batch gave the least strength of $9.267 \mathrm{~N} / \mathrm{mm}^{2}$, attaining a strength above the minimum strength of $6 \mathrm{~N} / \mathrm{mm}^{2}$ after 28 days of curing recommended by BSI. (1976) for masonry cement. Likewise, based on ACI-318-08 (ACI., 2008) acceptance criteria for standard-cured specimens for strength test, the compressive strength result of all pervious concrete batch mix were analyzed, the analysis outcome revealed that the control mix and $7 \%$ fines addition mix is considered satisfactory, since, the two conditions for acceptance criteria as stated in the methodology are satisfied.

Flexural strength: Experimental results of the fleexural strenth tests after 7,14 and 28 days. The optimum average 


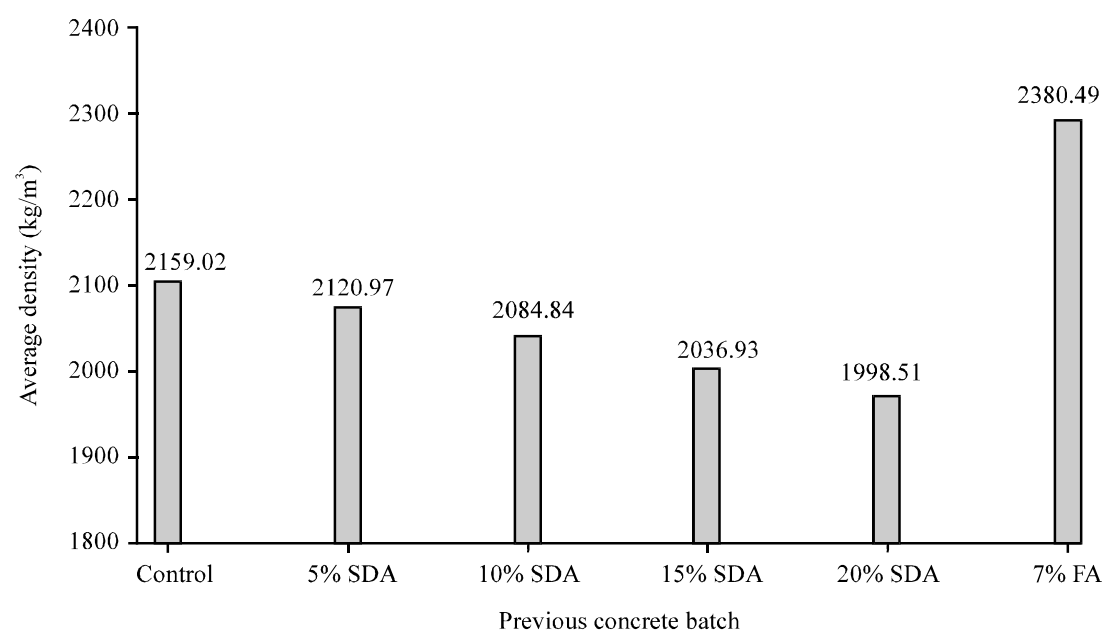

Fig. 2: Pervious concrete average density chart

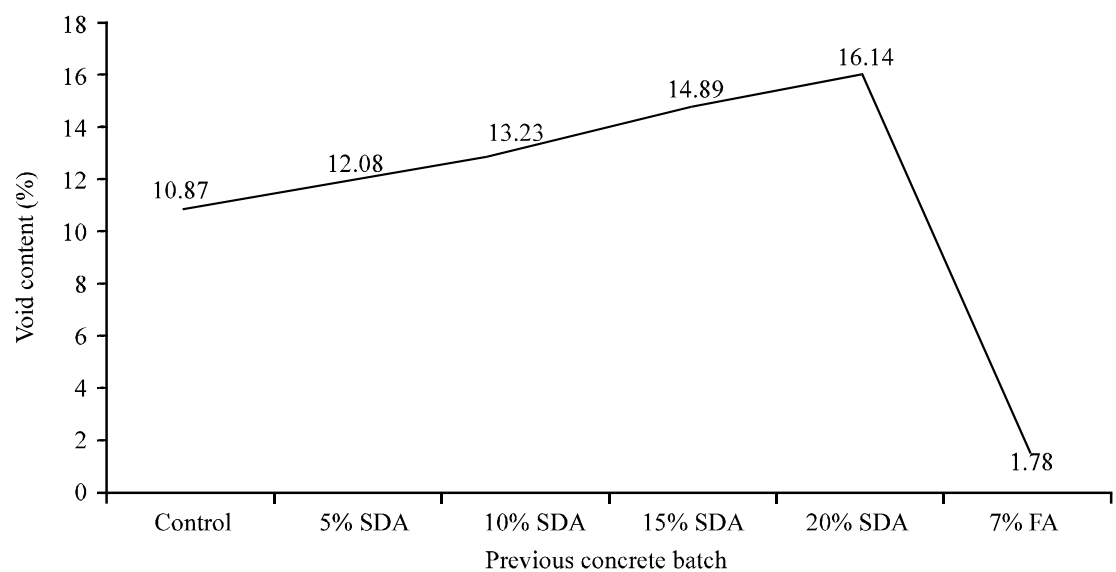

Fig. 3: Average void content (\%) of pervious concrete batch

Table 3: Experimental results of the compressive strength tests after 7,14 and 28 days

\begin{tabular}{|c|c|c|c|c|c|c|}
\hline \multirow[b]{2}{*}{$\underline{\text { Pervious concrete batch }}$} & \multicolumn{3}{|c|}{ Average load $(\mathrm{kN})$} & \multicolumn{3}{|c|}{ Average compressive strength $\left(\mathrm{N} / \mathrm{mm}^{2}\right)$} \\
\hline & 7 days & 14 days & 28 days & 7 days & 14 days & 28 days \\
\hline Control & 384.119 & 453.466 & 505.033 & 17.072 & 20.15 & 22.445 \\
\hline $5 \% \mathrm{SDA}$ & 182.246 & 233.570 & 251.753 & 8.099 & 10.38 & 11.189 \\
\hline $10 \%$ SDA & 172.026 & 214.990 & 235.534 & 7.646 & 9.55 & 10.468 \\
\hline $15 \% \mathrm{SDA}$ & 170.269 & 204.145 & 214.140 & 7.568 & 9.07 & 9.517 \\
\hline $20 \% \mathrm{SDA}$ & 162.574 & 202.500 & 208.517 & 7.225 & 9.00 & 9.267 \\
\hline $7 \% \mathrm{FA}$ & 427.243 & 496.280 & 547.422 & 18.988 & 22.05 & 24.329 \\
\hline
\end{tabular}

flexural strength for pervious concrete is 7.14 which is higher than the mean target flexural strength and falls above the pervious concrete flexural strength of approximately $2-5 \mathrm{~N} / \mathrm{mm}^{2}$ Table 4 . Nevertheless, all the pervious concrete mix are suitable to enjoy the maximum benefit of flexural strength gain as seen from the test result of the MOR range of approximately 3-7 N/mm . Correspondingly, based on ACI 318-08 (ACI., 2008) acceptance criteria for standard-cured specimens for strength test, the flexural strength result of all pervious concrete batch mix were examined, the analysis outcome revealed that the control mix and $7 \%$ fines addition mix is considered satisfactory, since, the two conditions for acceptance criteria as stated in the methodology are satisfied (Fig. 4).

Permeability/hydraulicconductivity test (infiltration rate method) Experimental results of permeability (Infiltration 
Table 4: Experimental results of the flexural strength tests after 7,14 and 28 days

\begin{tabular}{|c|c|c|c|c|c|c|}
\hline \multirow[b]{2}{*}{ Pervious concrete batch } & \multicolumn{3}{|c|}{ Average load $(\mathrm{kN})$} & \multicolumn{3}{|c|}{ Average Modulus of Rupture (MOR) $\left(\mathrm{N} / \mathrm{mm}^{2}\right)$} \\
\hline & 7 days & 14 days & 28 days & 7 days & 14 days & 28 days \\
\hline Control & 10.17 & 15.41 & 20.3 & 3.05 & 4.62 & 6.09 \\
\hline $5 \% \mathrm{SDA}$ & 11.16 & 11.28 & 11.48 & 3.34 & 3.38 & 3.44 \\
\hline $10 \% \mathrm{SDA}$ & 10.82 & 11.01 & 11.11 & 3.24 & 3.3 & 3.33 \\
\hline $15 \% \mathrm{SDA}$ & 10.43 & 10.68 & 10.94 & 3.13 & 3.2 & 3.28 \\
\hline $20 \% \mathrm{SDA}$ & 10.06 & 10.52 & 10.73 & 3.02 & 3.15 & 3.22 \\
\hline $7 \% \mathrm{FA}$ & 12.14 & 18.41 & 23.81 & 3.64 & 5.52 & 7.14 \\
\hline
\end{tabular}

Table 5: Experimental results for permeability (Infiltration rate test) at 28 days

\begin{tabular}{lcccccc}
$\begin{array}{l}\text { Pervious concrete } \\
\text { batch }\end{array}$ & $\begin{array}{c}\text { Diameter of cylindrical } \\
\text { mould }(\mathrm{cm})\end{array}$ & Mass of water $(\mathrm{kg})$ & Constant, $\mathrm{k}(\mathrm{h})$ & Time (sec) & $\begin{array}{c}\text { Infiltration } \\
\text { rate }(\mathrm{cm} / \mathrm{sec})\end{array}$ & $\begin{array}{c}\text { Void content } \\
(\%)\end{array}$ \\
\hline Control & 10 & 18.15 & 126,870 & 77 & 3.00 & 18.2 \\
$5 \%$ SDA & 10 & 18.15 & 126,870 & 65 & 3.06 & 19.1 \\
$10 \%$ SDA & 10 & 18.15 & 126,870 & 63.7 & 3.63 & 20.4 \\
$15 \%$ SDA & 10 & 18.15 & 126,870 & 61 & 3.78 & 22.0 \\
$20 \%$ SDA & 10 & 18.15 & 126,870 & 60 & 3.85 & 22.5 \\
$7 \%$ FA & 10 & 18.15 & 126,870 & 1100 & 0.21 & 5.20 \\
\hline
\end{tabular}

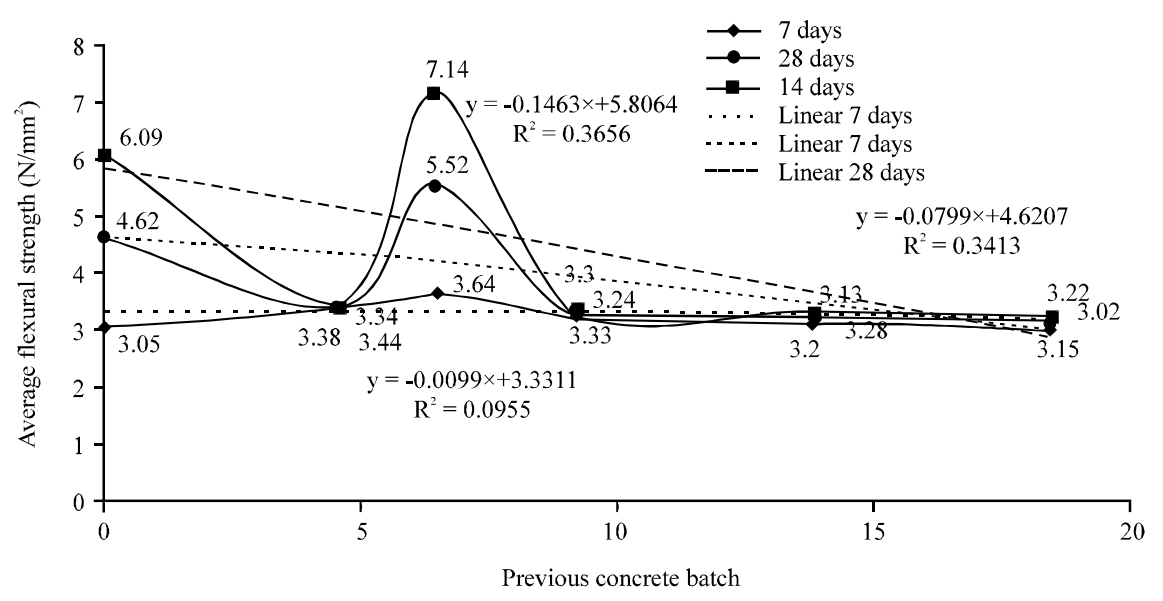

Fig. 4: Comparison of 7, 14 and 28 day's pervious concrete flexural strength

rate test) 28 days. Figure 5 shows that the infiltration rate is higher with an increase in SDA percentage replacement for pervious concrete due to the percentage of pores present in the PC specimens Table 5. It has been observed that $12.5 \mathrm{~mm}$ aggregate size gives higher values of permeability ranging from of $2.1-38.5 \mathrm{~mm} / \mathrm{sec}$ which is in conformity with sika pervious concrete guidebook. Figure 5 shows the relationship between void content and permeability as well as pervious concrete mix, respectively.

Clogged and unclogged pervious concrete pavement system: From the field testing method for permeability of pervious concrete, two water samples were utilized to determine the infiltration rate of water through the concrete, sample (A) having a mass of $3.62 \mathrm{~kg}$ of potable water and sample $(B)$ containing a water mass of $3.62 \mathrm{~kg}$ of polluted water. However, both samples were used for the permeability test, sample (A) was able to allow the flow of $3.62 \mathrm{~kg}$ mass of potable water within a time frame of $26 \mathrm{sec}$ which is directly proportional to $3.0 \mathrm{~cm} / \mathrm{sec}$ of infiltration rate, in contrast with sample (B) having the same mass of contaminated water but was able to allow flow of water in $2000 \mathrm{sec}$ which is directly proportional to $0.12 \mathrm{~cm} / \mathrm{sec}$ of infiltration rate.

Splitting tensile strength test: Experimental results of the split tensile strenth tests after 7,14 and 28 days. From Table 6 above, an optimum value of $2.52 \mathrm{~N} / \mathrm{mm}^{2}$ at 28 days was obtained for pervious concrete with $7 \%$ fines addition. It was concluded that $7 \%$ fines addition is adequate to enjoy the maximum benefit of strength gain. Figure 5 shows the effect of the pervious concrete batch on the split tensile strength of pervious concrete. As could be observed from Fig. 5, there is a general decrease in split tensile strength as the SDA content increases. The 


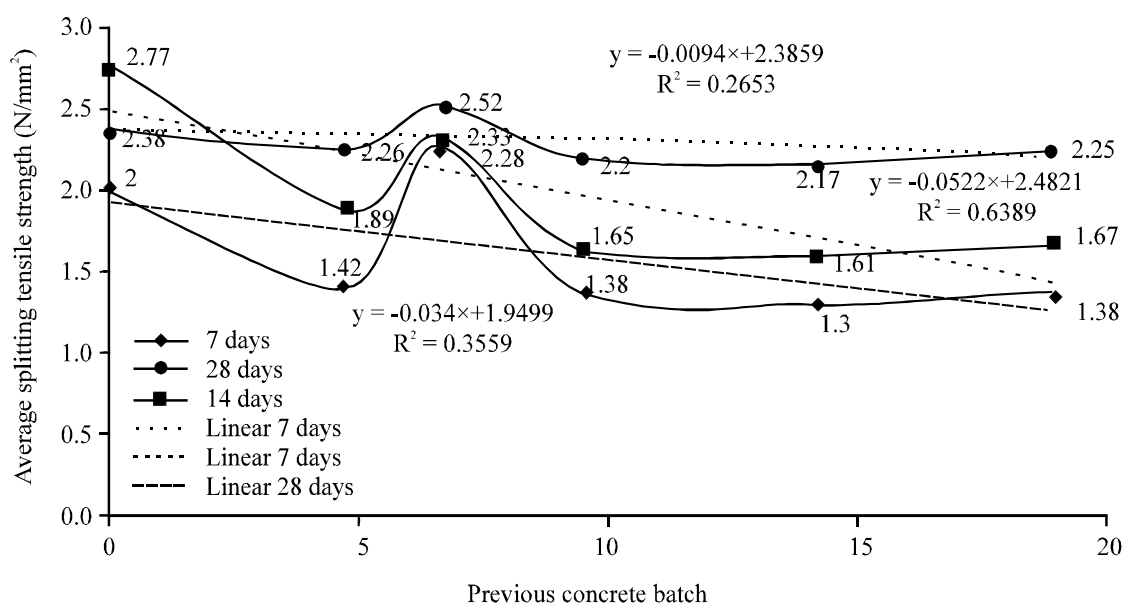

Fig. 5: Comparison of 7 days and 28 day's pervious concrete tensile splitting strength

Table 6: Experimental results of the split tensile strength tests after 7,14 and 28 days

\begin{tabular}{|c|c|c|c|}
\hline $\begin{array}{l}\text { Pervious concrete } \\
\text { batch }\end{array}$ & $\begin{array}{l}\text { Avg. splitting tensile strength } \\
\text { (d) } 7 \text { days }\left(\mathrm{N} / \mathrm{mm}^{2}\right)\end{array}$ & $\begin{array}{l}\text { Avg. splitting tensile strength } \\
\left(0,14 \text { days }\left(\mathrm{N} / \mathrm{mm}^{2}\right)\right.\end{array}$ & $\begin{array}{l}\text { Avg. splitting tensile strength } \\
\text { (a) } 28 \text { days }\left(\mathrm{N} / \mathrm{mm}^{2}\right)\end{array}$ \\
\hline Control & 2.00 & 2.77 & 2.38 \\
\hline $5 \%$ SDA & 1.42 & 1.89 & 2.26 \\
\hline $10 \%$ SDA & 1.38 & 1.67 & 2.25 \\
\hline $15 \%$ SDA & 1.38 & 1.65 & 2.20 \\
\hline $20 \%$ SDA & 1.30 & 1.61 & 2.17 \\
\hline $7 \% \mathrm{FA}$ & 2.28 & 2.33 & 2.52 \\
\hline
\end{tabular}

splitting tensile strength falls within pervious concrete splitting tensile strength of approximately $2-5 \mathrm{~N} / \mathrm{mm}^{2}$ (Shetty, 2004).

Likewise, based on ACI -318-08 (ACI., 2008) acceptance criteria for standard-cured specimens for strength test, for the splitting tensile strength result of all pervious concrete batch mix, it can be seen that the control mix and $7 \%$ fines addition mix is considered satisfactory, since, the two conditions for acceptance criteria are satisfied.

\section{CONCLUSION}

Based on the results of this study, the conclusions drawn are: SDA is a suitable material as a pozzolan having a combined $\left(\mathrm{SiO}_{2}+\mathrm{Al}_{2} \mathrm{O}_{3}+\mathrm{Fe}_{2} \mathrm{O}_{3}\right)$ of more than $70 \%$. Increase in SDA content makes concrete less workable thereby requiring higher water demand. The compressive strength generally increases with curing period and decreases with the increased amount of SDA. Only the control mix and $7 \%$ fines addition mix is adequate to enjoy the maximum benefit of strength gained. SDA concrete could be used for general concrete works where strength is of less importance such as in mass concrete, floor screed and mortar. All the pervious concrete mix are satisfactory to enjoy the maximum benefit of flexural strength gained. The splitting tensile strength generally increases with curing period and decreases with an increased percentage of SDA.

Finally, from this research work findings, it unveils that $\mathrm{PC}$ would be suitable as rigid pavement for high load road applications for $7 \%$ fines addition mix and control mix and for constructing plain concrete structures such as jetty structures, swimming pool decks, load-bearing walls, embankments etc., since, PC meets the minimum design criteria for grade 20 at 28 days thereby PC can be said to be a promising and beneficial in terms of cost.

\section{REFERENCES}

ACI., 2008. Building code requirements for structural concrete. American Concrete Institute, Farmington Hills, Michigan, USA.

ASTM, 2003. Standard Specification for Coal Fly Ash and Raw or Calcined Natural Pozzolan for use in Concrete. ASTM International, West Conshohocken, Pennsylvania, USA.,.

ASTM., 2009. ASTM-C1701/C1701M-09: Standard test method for infiltration rate of in place pervious concrete. ASTM International, Philadelphia, USA. https://www.astm.org/DATABASE.CART/HISTOR ICAL/C1701 C1701M-09.htm 
ASTM., 2015. Standard Test Method for Slump of Hydraulic-Cement Concrete. ASTM International, West Conshohocken, Pennsylvania, USA.,

ASTM., 2018a. ASTM-C150/C150M-18: Standard specification for portland cement. ASTM International, West Conshohocken, Pennsylvania, USA. https://www.astm.org/DATABASE.CART/ HISTORICAL/C150C150M-18.htm

ASTM., 2018b. ASTM-C989/C989M-18: Standard Specification for Slag Cement for Use in Concrete and Mortars. ASTM International, West Conshohocken, Pennsylvania, USA.,

Adesanya, D.A. and A.A. Raheem, 2009. A study of the workability and compressive strength characteristics of corn cob ash blended cement concrete. Construction Build. Mater., 23: 311-317.

Ajamu, S.O., A.A. Jimoh and J.R. Oluremi, 2012. Evaluation of structural performance of pervious concrete in construction. Int. J. Engin. Technol., 2: 829-836.

Al-Chaar, G.K., M. Alkadi, D.A. Yaksic and L.A. Kallemeyn, 2011. The use of natural pozzolan in concrete as an additive or substitute for cement. Master Thesis, US Army Corps of Engineers, Washington, DC., USA.

Atoyebi, O.D., A.E. Modupe, O.J. Aladegboye and S.V. Odeyemi, 2018c. Dataset of the density, water absorption and compressive strength of lateritic earth moist concrete. Data Brief, 19: 2340-2343.

Atoyebi, O.D., O.J. Aladegboye and S.V. Odeyemi, 2018a. Evaluation of laterized earth moist concrete in construction works. Intl. J. Civ. Eng. Technol., 9: $327-333$.

Atoyebi, O.D., S.O. Odeyemi, S.A. Bello and C.O. Ogbeifun, 2018b. Splitting tensile strength assessment of lightweight foamed concrete reinforced with waste tyre steel fibres. Intl. J. Civ. Eng. Technol., 9: 1129-1137.

BSI, 1976. Standard Specification for Masonry Cement. British Standard Institution, London.

BSI., 2003a. BS EN12390-3:2002: British standard testing hardened concrete Part 3: Compressive strength of test specimens. British Standards Institution, UK. https://www.slideshare.net/ZeljkoMarkovic5/bs-en $-12390-3$

BSI., 2003b. BS EN12390-6:2000: British Standard Testing Hardened Concrete Part 6: Tensile Splitting Strength of Test Specimens. British Standards Institution, $\mathrm{UK}$.,

BSI., 2003c. BS EN206-1:2000: Concrete-Part 1: Specification, Performance, Production and Conformity. British Standards Institution, UK.,.
BSI., 2009. BS EN12390-5:2009: Testing Hardened Concrete Part 5: Flexural Strength of Test Specimens. British Standards Institution, UK.,

Collier, C.G., 2016. Hydrometeorology. 1st Edn., Wiley-Blackwell, Hoboken, New Jersey, USA., ISBN:9781118414972, Pages: 376.

Dutt, K.S., K.V. Kumar, I.S. Kishore and M. Chowdary, 2016. Influence of natural fibers as an admix in normal concrete mix. Intl. J. Eng. Trends Technol., 35 : $1-5$.

Elinwa, A.U., S.P. Ejeh and A.M. Mamuda, 2008. Assessing of the fresh concrete properties of self-compacting concrete containing sawdust ash. Constr. Build. Mater., 22: 1178-1182.

Fakhrul, T., R. Mahbub and M.A. Islam, 2013. Properties of wood sawdust and wheat flour reinforced polypropylene composites. J. Mod. Sci. Technol., 1: 135-148.

Ghosh, S.K., A. Chaudhury, R. Datta and D.K. Bera, 2015. A review on performance of pervious concrete using waste materials. Intl. J. Res. Eng. Technol., 4: 105-115.

Harvey, J.T., J.A. Deacon, B.W. Tsai and C.L. Monismith, 1995. Fatigue performance of asphalt concrete mixes and its relationship to asphalt concrete pavement performance in California. Master Thesis, University of California, Berkeley, California.

Kotwa, A., 2015. Effect of selected admixtures on the properties of ordinary concrete. Procedia Eng., 108: 504-509.

Lee, M.J., M.G. Lee, Y. Huang and C.L. Chiang, 2013. Purification study of pervious concrete pavement. IACSIT. Intl. J. Eng. Technol., 5: 532-535.

Maguesvari, M.U. and V.L. Narasimha, 2013. Studies on characterization of pervious concrete for pavement applications. Procedia Soc. Behav. Sci., 104: 198-207.

Mahesh, B. and B. Lavanya, 2016. Experimental study of pervious concrete in pavements. Intl. J. Innovative Res. Sci. Eng. Technol., 5: 12913-12924.

Modupe, A.E., O.D. Atoyebi, A.O. Basorun, A.J. Gana and J.A. Ramonu et al., 2019. Development and performance evaluation of crumb rubber-bio-oil modified hot mix asphalt for sustainable highway pavements. Intl. J. Mech. Eng. Technol., 10: 273-287.

Mrakovcic, S., N. Ceh and V. Jugovac, 2014. Effect of aggregate grading on pervious concrete properties. Gradevinar, 66: 107-113.

Obla, K.H., 2010. Pervious concrete-An overview. Indian Concr. J., 84: 9-18. 
Patil, P. and S.M. Murnal, 2014. Study on the properties of pervious concrete. Intl. J. Eng. Res. Technol., 3: 819-822.

Radlinska, A., A. Welker, K. Greising, B. Campbell and D. Littlewood, 2012. Long-term field performance of pervious concrete pavement. Adv. Civ. Eng., 2012: $1-9$.

Sadiq, O.M. and O.D. Atoyebi, 2015. Flexural strength determination of reinforced concrete elements with waste glass as partial replacement for fine aggregates. NSE. Tech. Trans., 49: 74-81.
Sharma, S., S. Singla and T. Kaur, 2012. Mechanical properties of pervious concrete. Proc. Intl. Conf. Adv. Civ. Eng., 1: 161-164.

Shetty, M.S., 2004. Concrete Technology Theory and Practice. 5th Edn., S. Chand and Co. Ltd, New Delhi, India,

Zaetang, Y., V. Sata, A. Wongsa and P. Chindaprasirt, 2016. Properties of pervious concrete containing recycled concrete block aggregate and recycled concrete aggregate. Constr. Buil. Mater., 111: 15-21. 